\title{
PROSPEK DAN POTENSI PEMANFAATAN LIGNOSELULOSA JERAMI PADI MENJADI KOMPOS, SILASE DAN BIOGAS MELALUI FERMENTASI MIKROBA
}

\author{
R. Haryo Bimo Setiarto \\ Pusat Penelitian Biologi LIPI \\ Jalan Raya Jakarta-Bogor Km 46, Kawasan CSC Cibinong 16911, Jawa Barat \\ haryobimo42@yahoo.com
}

Diterima : 10 Juni 2013, Revisi akhir : 14 November 2013, Disetujui terbit : 02 Desember 2013

\section{PROSPECTS AND POTENTIAL OF RICE STRAW UTILIZATION OF LIGNOCELLULOSE INTO COMPOST, SILAGE AND BIOGAS BY MICROBIAL FERMENTATION}

\begin{abstract}
Microbial fermentation can processes lignocelluloses rice straw become several commodity with high value economics. Aerobic fermentation will results compost, and carbondioxyde. Meanwhile, anaerobic fermentation will results silase, biogas, and sludge. This review focused to doing comparative study about prospect and potency bioconversion rice straw to become biogas, silase, and compost by using microbial fermentation based on technoeconomical parameter. Compost from rice straw fermentation using Trichoderma sp., Trametes sp., and Aspergillus sp. which have quality: $\mathrm{C} / \mathrm{N}$ ratio (18.88), $\mathrm{C}(35.11 \%), \mathrm{N}(1.86 \%), \mathrm{P}_{2} \mathrm{O}_{5}(0.21 \%), \mathrm{K}_{2} \mathrm{O}(5,35 \%)$, water activity (55\%), Ca (4.2\%), Mg (0.5\%), Cu (20 ppm), Mn (684 ppm) and Zn (144 ppm). Moreover, silase from rice straw fermentation using Lactobacillus bulgaricus, Lactobacillus plantarum, and Plediococcus pentosomonas which have quality like acid flavour, it can not growth with fungi, it have green and yellow colour, pH 4.2, lactic acid composition (1.5-2.5\%), butyric acid concentration (0.1\%), acetic acid composition (0.5-0.8\%), and composition $\mathrm{N}-\mathrm{NH}_{3}(5-8 \%)$. Furthermore, biogas from rice straw fermentation using metanogenic bacteria (Methanobacterium and Methanobacillus) which have value $590-700 \mathrm{kcal}$ per cubic, so it can results electricity energy from 1.25 to $1.50 \mathrm{kWH}$. It was equivalen with $0.5 \mathrm{~kg}$ liquid natural gas, 0.5 litres premium, and 0.5 litres diesel oil. From technoeconomical aspect, it can concluded that prospect bioconversion rice straw become biogas is more profitable to be applied in Indonesia based on parameter Benefit Cost Ratio because it will be gotten two advantages from once processes which are product biogas and compost from residual sludge.
\end{abstract}

Keywords: rice straw, fermentation, compost, silase, biogas

\section{ABSTRAK}

Fermentasi mikroba mampu mengolah limbah lignoselulosa jerami padi menjadi beberapa komoditas dengan nilai ekonomi yang tinggi. Fermentasi secara aerob akan menghasilkan kompos, dan karbondioksida. Sementara itu proses fermentasi secara anaerob akan menghasilkan silase, biogas dan sludge. Review ini bertujuan melakukan studi komparatif terhadap prospek dan potensi pemanfaatan jerami padi menjadi biogas, silase maupun kompos melalui fermentasi mikroba ditinjau dari aspek teknis maupun ekonomis. Kompos jerami padi hasil fermentasi Trichoderma sp., Tremates sp., dan Aspergillus sp. memiliki kualitas: rasio C/N (18,88), C (35,11\%), N (1,86\%), $\mathrm{P}_{2} \mathrm{O}_{5}(0,21 \%), \mathrm{K}_{2} \mathrm{O}(5,35 \%)$, kadar air (55\%), Ca 4,2\%, Mg (0,5\%), Cu (20 ppm), Mn (684 ppm) dan Zn (144 ppm). Kualitas produk silase jerami padi hasil fermentasi Lactobacillus bulgaricus, Lactobacillus plantarum, dan Plediococcus pentosomonas adalah berbau asam, tidak berjamur, berwarna hijau kekuningan, memiliki pH 4,2; kandungan asam laktat 1,5-2,5\%, kandungan asam butirat $0,1 \%$, kandungan asam asetat 0,5-0,8\%; dan kandungan $\mathrm{N}_{-} \mathrm{NH}_{3} 5-8 \%$. Biogas jerami padi hasil fermentasi bakteri metanogenik Methanobacterium dan Methanobacillus memiliki nilai kalor 590 - 700 kkal per kubik, sehingga mampu membangkitkan energi listrik sebesar 1,25 - 1,50 kWH dan dapat disetarakan dengan 0,5 kg gas alam cair, 0,5 liter bensin, dan 0,5 liter minyak diesel. Secara ekonomi, prospek pemanfaatan jerami padi menjadi biogas lebih menguntungkan untuk diaplikasikan di Indonesia berdasarkan parameter Benefit Cost Ratio karena akan diperoleh dua keuntungan dalam satu kali proses produksi yaitu produk biogas serta kompos yang berasal dari sludge residu.

Kata kunci: jerami padi, fermentasi, kompos, silase, biogas 


\section{PENDAHULUAN}

Jerami merupakan bagian vegetatif berupa batang, daun, dan tangkai dari tanaman padi. Jerami padi merupakan limbah pertanian terbesar di Indonesia dengan ketersediaan sebesar 55 juta ton setahun yang tersebar sebagian besar di daerah Jawa Timur yaitu sebesar $31,27 \%$ (17,2 juta ton jerami padi), Jawa Tengah sebesar 23,79\% (13.08 juta ton jerami padi), Jawa Barat sebesar 15,19\% ( 8,35 juta ton jerami padi), Sulawesi Selatan sebesar 10,1\% (5,55 juta ton jerami padi), dan di Nusa Tenggara Barat sebesar 4,6\% (2,53 juta ton jerami padi) (Syamsu, 2006). Karena jumlahnya yang melimpah jerami padi mudah diperoleh dan sangat ekonomis (murah).

Dari ketersediaan jerami padi tersebut baru sekitar 31-32\% yang dimanfaatkan sebagai pakan ternak, sebesar 36-38\% dimanfaatkan sebagai pupuk, serta $7-8 \%$ yang dimanfaatkan sebagai bahan baku industri pulp dan kertas, sehingga diestimasikan sebesar $22-25 \%$ jerami padi masih belum bisa dimanfaatkan dengan optimal. Sesungguhnya jerami padi masih memiliki banyak potensi bagi kehidupan masyarakat diantaranya dapat diolah menjadi sumber energi alternatif seperti biogas maupun bioetanol dengan fermentasi mikroba. Peningkatan nilai manfaat jerami perlu dilakukan, mengingat potensinya yang sangat besar dan tidak ada habis-habisnya selama padi masih menjadi makanan pokok masyarakat Indonesia (Hartono dan Kurniawan, 2009).

Komposisi kimia jerami padi ditandai oleh rendahnya kadar nitrogen dan mineral esensial, sedangkan kadar serat kasarnya tinggi, sehingga kecernaanya mencapai $37 \%$. Jerami padi mengandung $21 \%$ inti sel dan $79 \%$ dinding sel berdasarkan berat kering. Dari $79 \%$ berat kering ini terdiri dari $26 \%$ hemiselulose, $33 \%$ selulosa, 7\% lignin, dan silika 13\% (Syamsu, 2006). Kandungan dinding sel terutama lignin bertambah dengan meningkatnya umur tanaman. Pada waktu tanaman padi dipanen, jerami adalah bagian tanaman yang tidak diambil. Produksi jerami padi dihasilkan sekitar $50 \%$ dari produksi gabah kering panen. Perbandingan antara bobot gabah yang dipanen dengan jerami padi (grain straw ratio) pada saat panen pada umumnya 2:3. Pada saat produksi gabah nasional 54 juta ton pada tahun 2005 , berarti terdapat 80 juta ton jerami yang dihasilkan pada tahun tersebut, pada tahun 2010 diperkirakan produksi jerami padi mencapai 84 juta ton (Hartono dan Kurniawan, 2009).

Dilihat dari segi daur ulang, tentu sangatlah jelas bahwa jerami padi dapat didaur ulang kembali menjadi produk yang lebih bermanfaat khususnya kompos yang menyediakan unsur hara bagi tanah dan biogas sebagai bahan bakar alternatif pengganti elpiji. Dari segi penggunaan ulang, penggunaan limbah jerami dapat dipergunakan secara terus menerus untuk dapat memenuhi kebutuhan pakan ternak dalam bentuk silase (Murni dkk., 2008). Dilihat dari segi pengurangan limbah, abu jerami padi banyak dimanfaatkan oleh petani karena mengandung kalium yang tinggi dan sangat diperlukan oleh tanaman padi. Di samping itu limbah jerami juga dapat dimanfaatkan sebagai bahan baku untuk industri pulp dan kertas.

Untuk meningkatkan produktivitas di sektor pertanian dalam upaya mencapai swasembada pangan diperlukan perbaikan kualitas lahan pertanian melalui peningkatan kandungan unsur hara dalam tanah. Salah satu solusinya adalah dengan mengubah jerami padi menjadi kompos. Sebagaimana yang diketahui jerami padi mengandung bahan-bahan organik yang dapat menyuburkan tanah (Husen dkk., 2007). Mikroba lignoselulolitik dari kelompok bakteri dan fungi sangat berperan dalam proses fermentasi jerami padi menjadi kompos (Jin dan Chen, 2006). Mikroba lignoselulolitik tersebut dimanfaatkan sebagai starter inokulan kompos karena memiliki kemampuan untuk menghasilkan enzim lakase, selulase, maupun xilanase yang secara berturut-turut mampu menghidrolisis senyawa lignin, selulosa maupun hemiselulosa yang banyak terkandung dalam jerami padi (Howard dkk., 2003). Selulase merupakan enzim yang dapat menghidrolisis ikatan $\beta-1,4$ glukosida pada selulosa dan turunannya. Enzim ini dapat mengubah selulosa tak tersubstitusi menjadi selobiosa yang kemudian dihidrolisis lebih lanjut dengan $\beta$-glukosidase (Sukumaran dkk., 2005). Pemutusan ikatan ini menghasilkan oligosakarida turunan selulosa, untuk akhirnya diubah menjadi monomer glukosa. Selulase termasuk sistem multienzim yang terdiri dari endoglukanase (EC.3.2.1.4), selobiohidrolase (EC.3.2.1.91), dan $\beta$-glukosidase (EC.3.2.1.21) (Ahamed dan Vermette, 2008). 
Xilanase merupakan kelompok enzim yang memiliki kemampuan menghidrolisis xilan atau polimer dari xilosa (Saha, 2003). Xilanase dapat diklasifikasikan berdasarkan substrat yang dihidrolisis, yaitu $\beta$-xilosidase, eksoxilanase, dan endoxilanase. Eksoxilanase mampu memutus rantai polimer xilosa (xilan) pada ujung reduksi, sehingga menghasilkan xilosa sebagai produk utama dan sejumlah oligosakarida rantai pendek (Da Silva dkk., 2005; Dewi 2002). Lakase (benzendiol: oksigen oxidoreductase, EC 1.10.3.2) merupakan enzim ekstraseluler yang menggunakan senyawa oksigen untuk menjalankan reaksi oksidasi berbagai senyawa aromatik dan nonaromatik. Enzim ini termasuk ke dalam kelas enzim oksidase yang memerlukan ion logam. Dalam kinerjanya enzim lakase hanya memerlukan oksigen dan menghasilkan air sebagai satu-satunya produk samping.

Beberapa genus fungi Basidiomycetes diantaranya Trametes versicolor, Marasmius sp., Irpex lacteus, Heterobasidium annosum, Phanerochaete chrysosporium, Ganoderma australe, Phlebia tremellosa, Pleurotus spp dan Phelinus pini memiliki kemampuan menghasilkan enzim lakase (Couto dkk., 2007). Genus tersebut sebagian besar merupakan kelompok jamur pengurai kayu dengan kemampuan mendegradasi lignin dan melakukan dekomposisi. Lakase merupakan hasil metabolisme sekunder dari jamur pelapuk putih dengan kondisi keterbatasan sumber karbon dan nitrogen (Taniguchi dkk., 2005). Sementara itu enzim selulase dan xilanase banyak dihasilkan oleh beberapa spesies fungi diantaranya Trichoderma viridae, Trichoderma longibrachiatum, Trichoderma reseei, Aspergillus niger, Aspergillus fumigatus, Aspergillus nidulans, Neurospra sitophila dan Penicillium sp. (Saha, 2004). Selain fungi ada beberapa genus bakteri diantaranya Bacillus subtilis dan Pseudomonas aeruginosa yang mampu menghasilkan kedua enzim tersebut (Singhania, 2009).

Masalah lain yang juga sedang dihadapi oleh pemerintah adalah sektor peternakan yaitu terbatasnya sediaan pakan hijauan ternak (silase) yang keberadaannya sangat dipengaruhi faktor musim. Pada musim penghujan silase tersedia dalam jumlah banyak sedangkan pada musim kemarau ketersediaannya sangat terbatas. Hal ini yang menjadi kendala dalam upaya pemerintah untuk meningkatkan produksi ternak dan mengurangi volume impor daging. Untuk mengatasi hal tersebut peternak memberi pakan sisa-sisa pertanian seperti jerami padi. Akan tetapi kendala utama dari pemanfaatan jerami padi sebagai salah satu bahan pakan ternak adalah kandungan serat kasar tinggi, sementara itu kandungan protein dan kecernaannya rendah. Penggunaan jerami secara langsung atau sebagai pakan tunggal tidak dapat memenuhi pasokan nutrisi yang dibutuhkan ternak. Hal ini disebabkan karena adanya faktor pembatas yaitu rendahnya kandungan protein kasar, serta tingginya serat kasar, lignin, silika. Untuk itu, jerami padi perlu ditingkatkan nilai nutrisi dan dayacernanya melalui fermentasi mikroba (Yunilas, 2009).

Fermentasi silase dari jerami padi dapat berjalan dengan baik dalam kondisi aerob maupun anaerob dan didominasi oleh bakteri penghasil asam laktat yang bersifat fakultatif anaerob. Bakteri yang memfermentasi jerami padi mempunyai ciri yaitu memproduksi asam laktat dengan jumlah bakteri asam laktat $7.6 \times 10^{6}$ dalam silase. Lactobacillus bulgaricus merupakan salah satu bakteri penghasil asam laktat yang dapat digunakan sebagai starter dalam pembuatan silase. Lactobacillus bulgaricus adalah bakteri berbentuk batang, tumbuh pada suhu $15-45^{\circ} \mathrm{C}$, tidak tahan garam, merupakan bakteri asam laktat homofermentatif yang mengubah glukosa menjadi asam laktat. Stimulan fermentasi bekerja membantu pertumbuhan bakteri asam laktat sehingga kondisi asam segera tercapai. Stimulan tersebut akan meningkatkan populasi bakteri asam laktat dalam bahan pakan. Sementara itu inhibitor fermentasi digunakan untuk menghambat pertumbuhan mikroorganisme pembusuk seperti Clostridia sehingga pakan bisa awet, sebagai contohnya yaitu asam-asam organik seperti asam format, propionat dan laktat. Salah satu penambahan zat aditif sebagai stimulan fermentasi silase yaitu dengan bakteri asam laktat seperti Lactobacillus plantarum, Pledioccus pentosomonas.

Selain peningkatan produktivitas pertanian dan peternakan, salah satu permasalahan utama yang dihadapi bangsa Indonesia adalah tingkat konsumsi energi yang semakin tinggi, sedangkan sumber energi fosil terbatas. Oleh karena itu diperlukan usaha-usaha untuk mendapatkan energi terbarukan. Strategi pemerintah dengan mensubstitusi sebagian kebutuhan energi fosil dengan energi alternatif terbarukan dari sumber nabati seperti biodiesel dari minyak sawit kasar (CPO/Crude Palm Oil) atau jarak 
pagar (Jatropha curcas, L.), singkong dan tebu, telah menyebabkan kompetisi dengan kebutuhan pangan dan berpotensi mengancam ketahanan pangan. Salah satu alternatif untuk memecahkan kedua masalah tersebut di atas adalah pemanfaatan sumberdaya yang selama ini belum dikelola secara maksimum. Sebagai solusinya, ketersediaan limbah pertanian jerami padi yang melimpah dapat dimanfaatkan sebagai sumber energi alternatif biogas untuk mengatasi kelangkaan energi dan memperoleh energi terbarukan. Jerami padi berpotensi dikonversi menjadi biogas melalui fermentasi mikroba dengan nilai konversi jerami menjadi biogas mencapai 250-350 liter/kg berat kering (Deublin dan Strainhauser, 2008). Terdapat tiga kelompok bakteri yang berperan dalam biokonversi jerami padi menjadi biogas yaitu: 1. Kelompok bakteri fermentatif, yaitu: Streptococci, Bacteriodes, dan beberapa jenis genus Enterobactericeae yang sangat berperan dalam tahapan hidrolisis jerami padi; 2. Kelompok bakteri asetogenik, yaitu Desulfovibrio yang bertanggungjawab selama tahapan asidogenesis; dan 3. Kelompok bakteri metana, yaitu Methanobacterium, Methanobacillus, Methanosacaria, dan Methanococcus yang berkontribusi pada proses metanogenesis. Ketiga kelompok bakteri tersebut bekerja sama dalam pembentukan biogas, walaupun yang mendominasi fermentasi metana (biogas) adalah jenis Methanobacterium.

Persyaratan kompos jerami yang layak dimanfaatkan sebagai pupuk tanaman antara lain: berwarna coklat tua hingga hitam mirip dengan warna tanah, tidak larut dalam air meski sebagian kompos dapat membentuk suspensi, rasio $\mathrm{C} / \mathrm{N}$ sebesar $10-20$, suhunya kurang lebih sama dengan suhu lingkungan (untuk lingkungan tropis $27-30^{\circ} \mathrm{C}$ ), memiliki kadar air bahan sebesar 50 - 60\% dan tidak berbau (Rachman dkk., 2006). Adapun persyaratan kualitas produk biogas yang bermutu dari bahan baku jerami padi sebagai bahan bakar antara lain adalah biogas mampu menghasilkan suhu pembakaran $270^{\circ} \mathrm{C}-280^{\circ} \mathrm{C}$, memiliki kandungan oksigen $0,1 \%$, metana $54-$ $70 \%$, karbondioksida $27-35 \%$, nitrogen $0,5-2 \%$, karbonmonoksida $0,1 \%$, hidrogen sulfida $0-3 \%$, dan hidrogen 1-5\% (Hartono dan Kurniawan, 2009). Sementara itu persyaratan silase yang baik sebagai pakan ternak dapat diketahui melalui uji organoleptik dan pengujian secara kimiawi. Secara organoleptik ciri-ciri silase yang baik antara lain: mempunyai tekstur segar, berwarna kehijau-hijauan, disukai ternak ruminansia, tidak berbau, tidak berjamur dan tidak menggumpal. Sementara itu secara kimiawi silase yang baik memiliki temperatur $27-35^{\circ} \mathrm{C}$ dan $\mathrm{pH} 4,2-4,8$; mengandung asam laktat, tidak mengandung asam butirat, kadar $\mathrm{N}$ ammonia rendah (kurang dari 10\%) (Yulinas, 2009).

Review ini bertujuan untuk melakukan studi komparatif terhadap prospek dan potensi pemanfaatan jerami padi menjadi biogas, silase maupun kompos melalui fermentasi mikroba ditinjau dari aspek teknis maupun ekonomis. Hasil studi komparatif ini selanjutnya diharapkan dapat memberikan masukan bagi pemerintah, stakeholder, serta pengambil kebijakan dalam memanfaatkan limbah lignoselulosa jerami padi dengan efektif dan efisien.

\section{BAHAN DAN METODE}

\section{Peralatan dan Bahan}

\section{a. Pembuatan Kompos}

Bahan yang digunakan adalah jerami padi, larutan starter yang mengandung mikroba Trichoderma sp., Aspergillus sp., dan Trametes sp., dan air untuk menyiram timbunan kompos. Peralatan pendukung yang diperlukan adalah bak kompos berukuran panjang $1 \mathrm{~m}$, lebar $1 \mathrm{~m}$, dan tinggi 1-1,25 m sebanyak 5 buah, plastik warna gelap berukuran $1 \mathrm{~m}$ x $5 \mathrm{~m}$ dan $2 \mathrm{~m}$ x $2 \mathrm{~m}$ masingmasing satu lembar, tali rafia untuk mengikat timbunan kompos, ember, gayung (Setyorini dkk., 2006).

\section{b. Pembuatan Silase}

Alat utama untuk membuat silase adalah mesin pencacah (chopper). Mesin ini terdiri dari bilah pisau yang berputar, dengan tenaga penggerak berbahan bakar bensin maupun solar. Silo merupakan bangunan permanen berupa tembok, beton, besi, seng atau bahan lain. Untuk kapasitas jerami padi 10 ton dapat dibuat bangunan silo dengan ukuran 4 x $5 \mathrm{~m}$. Lantai dasar dibuat dari semen atau tanah yg dipadatkan serta ditinggikan dari tempat sekitarnya, tanpa dinding. Bahan bangunan dapat menggunakan kayu/ bambu. Atapnya dapat berupa seng atau bahan lain yg tersedia di tempat. Untuk jarak lantai sampai dengan atap kira-kira $3 \mathrm{~m}$. 


\section{c. Pembuatan Biogas}

Instalasi biogas merupakan digester yang berfungsi untuk menampung gas metan hasil perombakan bahan bahan organik oleh bakteri. Jenis digester yang banyak digunakan adalah model continuous feeding. Besar kecilnya digester tergantung pada volume jerami padi dan banyaknya biogas yang ingin diproduksi. Pada umumnya luas lahan yang diperlukan untuk membangun digester adalah sekitar $16 \mathrm{~m}^{2}$. Beberapa kelengkapan dari instalasi biogas adalah saluran masuk slurry, saluran keluar residu, katup pengaman tekanan (control valve), sistem pengaduk, saluran gas dan tangki penyimpan gas.

\section{Mekanisme Pemanfaatan Jerami Padi}

\section{a. Pembuatan Kompos}

Pembuatan Kompos dapat dilakukan di dalam bak atau pada lahan sawah.

\section{Pembuatan di dalam bak}

Lapisan pertama jerami padi dimasukkan ke dalam bak dengan tinggi tumpukan 20-25 cm, lalu disiram agar lembab. Selanjutnya tumpukan jerami padi disiram dengan larutan starter secara merata per lapisan. Lanjutkan dengan pembuatan lapisan kedua dan seterusnya sampai tinggi tumpukan jerami kira-kira tiga perempat bak kompos atau 80-90 cm. Untuk mempercepat proses penguraian, pada setiap lapisan diberi kapur atau abu dapur. Tumpukkan kompos harus cukup basah dan terlindung dari cahaya matahari dan hujan (Husen dkk., 2007). Bak berisi jerami yang siap dikomposkan lalu ditutup dengan plastik berwarna gelap.Setelah satu minggu, kompos dibalik agar panasnya merata dan pengomposan berlangsung sempurna. Pengomposan jerami padi dengan aktivator mikroba lignoselulolitik umumnya memerlukan waktu fermentasi selama 2 minggu. Kompos yang telah matang akan berwarna hitam kecoklatan dengan suhu sekitar $30^{\circ} \mathrm{C}$, kelembaban 40-60\%, dan tidak mengeluarkan bau.

\section{Pembuatan dilahan sawah}

Pembuatan kompos dilakukan di sudut petakan sawah dengan ukuran $2 \mathrm{~m}$ x $5 \mathrm{~m}$ atau lebih luas, bergantung pada jerami padi yang tersedia. Jerami ditumpuk rata setinggi
20-25 cm di dalam area yang sudah diberi batas patok, lalu disiram air dan diberi larutan starter secara merata. Demikian seterusnya sampai tinggi tumpukan jerami mencapai 1,25 m, lalu ditutup dengan plastik berwarna gelap. Satu minggu kemudian kompos dibalik. Pembalikan dilakukan secara bertahap per lapisan mulai lapisan atas sampai lapisan bawah. Satu minggu berikutnya kompos jerami dapat disebar di lahan sawah dan diaduk bersama tanah (Rachman dkk., 2006).

\section{b. Pembuatan Silase}

Pembuatan silase dibagi menjadi empat tahapan yaitu: persiapan bahan jerami padi; pencampuran, fermentasi dan produksi silase. Jerami padi dipotong-potong dengan ukuran sekitar 3-5 cm, untuk memudahkan proses pencampuran dengan bahan lainnya. Pencampuran dilakukan dengan menggunakan mixer atau mesin pencampur. Untuk pencampuran dalam skala kecil, dapat dilakukan secara manual dengan menggunakan sekop. Proses pencampuran dilakukan secara merata, untuk menghasilkan silase yang berkualitas baik. Proses fermentasi dilakukan pada kondisi anaerob yaitu pada suhu $25^{\circ} \mathrm{C}-37^{\circ} \mathrm{C}$ dan pada $\mathrm{RH}$ (kelembapan) mencapai 25-30\%, serta $\mathrm{pH} 3,8-4,2$. Silase merupakan hasil dari proses fermentasi. Namun, produk fermentasi tersebut masih mengandung sejumlah gas. Kondisi ini dapat menekan konsumsi dan dapat berbahaya bagi ternak. Oleh karena itu, sebelum diberikan pada ternak, silase perlu diangin-anginkan terlebih dahulu, untuk menghilangkan aromanya yang menyengat, dan juga perlu dilakukan uji terhadap logam-logam berat yang mungkin mencemarinya.

\section{c. Pembuatan Biogas}

Mekanisme pembentukan biogas dari jerami padi melalui fermentasi bakteri terdiri dari 3 tahapan yaitu hidrolisis, asidogenesis dan metanogenesis. Diagram alir mekanisme biokonversi jerami padi menjadi biogas dapat dilihat pada Gambar 1 .

Hidrolisis merupakan penguraian senyawa kompleks menjadi senyawa yang sederhana. Pada tahap ini bahan yang tidak larut seperti selulosa, polisakarida dan lemak diubah menjadi bahan yang larut dalam air seperti 
karbohidrat dan asam lemak. Tahap pelarutan berlangsung pada suhu $25^{\circ} \mathrm{C}$ di dalam digester (Mosier dkk., 2005).

Asidogenesis merupakan pembentukan asam dari senyawa sederhana. Bakteri asidogen pada tahap ini memproses senyawa terlarut menjadi asam-asam lemak rantai pendek yang umumnya berupa asam asetat dan asam format dalam suasana anaerob. Tahap ini berlangsung pada suhu $25^{\circ} \mathrm{C}$ di dalam digester.

Metanogenesis adalah proses pembentukan gas metan secara anaerobic dengan bantuan bakteri metanogenik seperti Methanobacterium, Methanobacillus, Methanosacaria, dan Methanococcus. Tahap ini mengubah asam asam lemak rantai pendek menjadi $\mathrm{H}_{2}, \mathrm{CO}_{2}$, dan asetat. Asetat akan mengalami dekarboksilasi dan reduksi $\mathrm{CO}_{2}$, kemudian bersama-sama dengan $\mathrm{H}_{2}$ dan $\mathrm{CO}_{2}$ menghasilkan produk akhir, yaitu gas metana $\left(\mathrm{CH}_{4}\right)$ dan karbondioksida $\left(\mathrm{CO}_{2}\right)$. Proses ini berlangsung selama 14 hari pada suhu $25^{\circ} \mathrm{C}$ (Taherzadeh dan Karimi, 2008).

Tata cara pembuatan biogas adalah jerami padi yang berukuran 4-5 cm dimasukkan ke dalam bak penampung dan ditambahkan air dengan perbandingan air dan jerami padi 1:3. Kemudian dimasukkan ke dalam digester hingga penuh. Diamkan selama 30-45 hari dan lakukan pengadukan setiap lima hari sekali. Supaya produksi gas dapat dilakukan setiap hari, tambahkan campuran $2 \mathrm{~kg}$ cacahan jerami padi dan 6 liter air ke dalam digester (Deublein dan Steinhauser, 2008).

\section{HASIL DAN PEMBAHASAN}

\section{Karakteristik Jerami Padi}

Jerami padi yang kaya akan kandungan lignoselulosa dapat dikonversi melalui fermentasi mikroba baik secara aerob maupun anaerob. Hasil akhir dari kedua macam fermentasi tersebut berbeda, tergantung dari proses maupun mekanisme yang digunakan. Fermentasi secara aerob akan menghasilkan kompos dan karbon dioksida $\left(\mathrm{CO}_{2}\right)$. Sementara itu proses fermentasi secara anaerob akan menghasilkan silase, biogas dan sludge (Taherzadeh dan Karimi, 2008).

Kandungan lignin sebesar 7\% dalam jerami padi dapat dihidrolisis oleh fungi dari spesies Trichoderma sp., Aspergillus sp., maupun Trametes sp. yang mampu menghasilkan enzim ligninase (manganese peroksidase, lakase maupun lignin peroksidase) pada kondisi aerobik. Ketiga genus fungi tersebut juga dikenal mampu mengkonversi komponen selulosa jerami padi sebesar $(33 \%)$ menjadi glukosa dan hemiselulosa (26\%) pada jerami padi menjadi xilosa dan mannosa yang akan dimanfaatkan sebagai sumber C (Saha, 2004). Berlangsungnya hidrolisis oleh ketiga mikroba lignoselulolitik tersebut akan menyebabkan

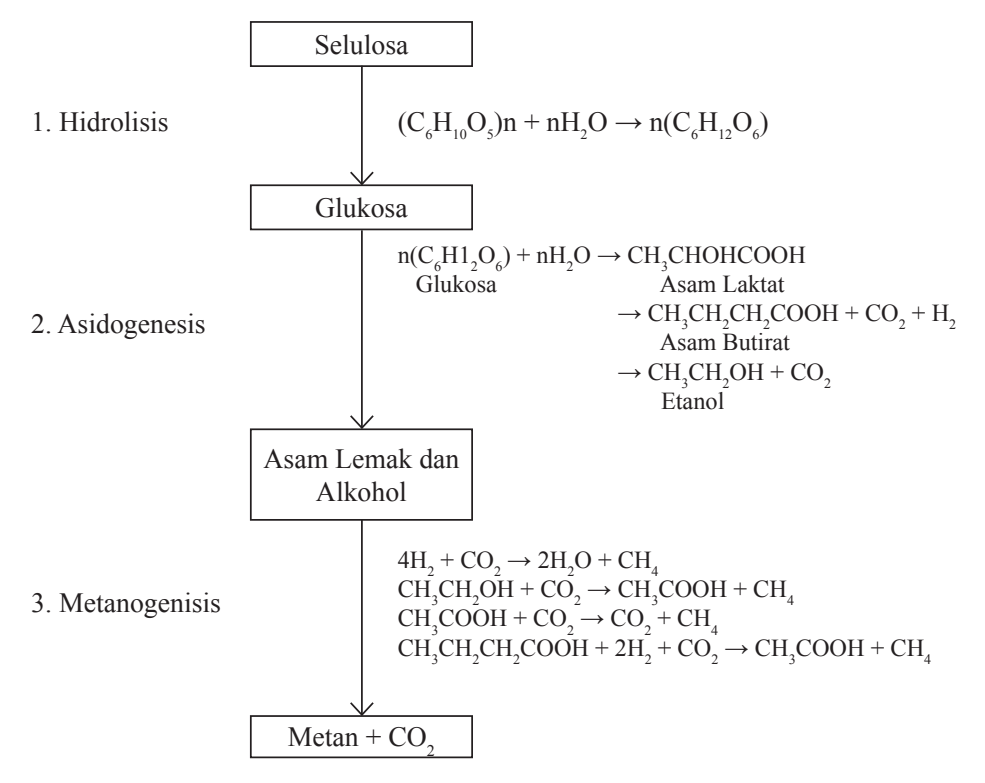

Gambar 1. Mekanisme Jerami Padi menjadi Biogas 
terjadinya pengomposan yang ditandai dengan perubahan tekstur, dan warna jerami padi menjadi coklat kehitaman. Kompos jerami yang terbentuk melalui proses fermentasi juga akan mengalami peningkatan kandungan karbon $(\mathrm{C})$, nitrogen $(\mathrm{N})$, kalium $\left(\mathrm{K}_{2} \mathrm{O}\right)$, fosfat $\left(\mathrm{P}_{2} \mathrm{O}_{5}\right)$, kalsium, magnesium, serta senyawa mikromineral $(\mathrm{Cu}, \mathrm{Mn}$, dan $\mathrm{Zn})$. Di samping itu keberadaan senyawa metabolit sekunder seperti asam indol asetat (auksin) yang dihasilkan selama pengomposan oleh fungi merupakan hormon pertumbuhan yang penting bagi tanaman (Saha, 2003).

Komposisi kimia jerami padi terdiri dari: bahan kering $71,2 \%$, protein kasar 3,9\%, lemak kasar $1,8 \%$, serat kasar $28,8 \%$, bahan ekstrak tanpa nitrogen $37,1 \%$, silikat $13 \%$. Dengan kandungan nutrisi yang rendah hewan ternak yang hanya mendapatkan jerami saja sebagai pakannya akan memiliki produktivitas rendah karena tingkat ketercernaan nutrisi jerami padi hanya 40,2\%. Oleh karena itu diperlukan fermentasi anaerob dengan memanfaatkan bakteri asam laktat untuk meningkatkan nutrisi jerami padi

Penelitian Syamsu (2006) menghasilkan bahwa komposisi nutrisi jerami padi yang telah difermentasi dengan menggunakan starter mikroba Lactobacillus bulgaricus, Lactobacillus plantarum, dan Pledioccus pentosomonas sebanyak $0,06 \%$ dari berat jerami padi. Secara umum memperlihatkan peningkatan kualitas apabila dibandingkan dengan jerami padi yang tidak difermentasi. Selanjutnya diketahui bahwa kadar protein kasar jerami padi yang difermentasi mengalamipeningkatandari 4,23\% menjadi 8,14\% dan diikuti dengan penurunan kadar serat kasar. Hal ini memberikan indikasi bahwa starter bakteri asam laktat yang merupakan mikroba proteolitik penghasil protease dapat merombak protein menjadi polipeptida yang selanjutnya menjadi peptida sederhana. Selanjutnya Syamsu (2006) juga menyatakan bahwa penggunaan starter mikroba menurunkan kadar dinding sel jerami padi dari $73,41 \%$ menjadi $66,14 \%$. Dengan demikian selama fermentasi telah terjadi pemutusan ikatan lignoselulosa dan hemiselulosa sehingga selulosa dan lignin dapat terlepas dari ikatan tersebut oleh ligninase. Fenomena ini terlihat dengan menurunnya kandungan selulosa dan lignin jerami padi yang difermentasi. Menurunnya kadar lignin menunjukkan selama fermentasi terjadi penguraian ikatan lignin dan hemiselulosa. Lignin merupakan benteng pelindung fisik yang menghambat daya cerna enzim terhadap jaringan tanaman dan lignin berkaitan erat dengan hemiselulosa. Di sisi lain, dengan menurunnya kadar dinding sel jerami padi menunjukkan telah terjadi pemecahan selulosa dinding sel sehingga pakan akan lebih mudah dicerna oleh ternak.

Pembuatan biogas dari jerami padi juga dilakukan melalui fermentasi anaerobik, dengan memanfaatkan bakteri Streptococci, Bacteriodes, dan beberapa genus Enterobactericeae yang mampu menghidrolisis senyawa protein kasar $(3,9 \%)$, lemak kasar (1,8\%), selulosa sebesar 33\%, dan hemiselulosa sebesar $26 \%$ menjadi senyawa dengan rantai pendek seperti peptida, asam amino, asam lemak, gliserol dan gula sederhana (glukosa, xilosa, dan mannosa). Selanjutnya senyawa rantai pendek hasil hidrolisis tersebut dikonversi menjadi senyawa asam karboksilat rantai pendek seperti asam format dan asam asetat oleh bakteri asidogen Desulfovibrio. Sampai akhirnya bakteri metanogenik seperti Methanobacterium, Methanobacillus, Methanosacaria, dan Methanococcus mengubah asam-asam karboksilat tersebut menjadi $\mathrm{H}_{2}, \mathrm{CO}_{2}$, dan asetat. Asetat akan mengalami dekarboksilasi dan reduksi $\mathrm{CO}_{2}$, kemudian bersama-sama dengan $\mathrm{H}_{2}$ dan $\mathrm{CO}_{2}$ menghasilkan produk akhir, yaitu gas metan $\left(\mathrm{CH}_{4}\right)$ dan karbondioksida $\left(\mathrm{CO}_{2}\right)$.

\section{Pemanfaatan Jerami Padi menjadi Kompos}

Hasil penelitian menunjukkan bahwa aplikasi kompos jerami selama 4-6 musim di Jepang dan China, mampu meningkatkan kesuburan tanah dan meningkatkan produktivitas tanaman padi sekitar 25\%. Dari 1 ton jerami padi dapat diperoleh 0,5 ton sampai 0,67 ton kompos jerami. Dengan demikian jika kita ingin membuat satu ton kompos, maka bahan baku jerami yang disiapkan sekitar 1,5-2 ton jerami. Kandungan kualitas beberapa unsur hara untuk 1 ton kompos jerami padi adalah : rasio $\mathrm{C} / \mathrm{N}(18,88)$, kadar $\mathrm{C}(35,11 \%)$, kadar $\mathrm{N}$ $(1,86 \%)$, kadar $\mathrm{P}_{2} \mathrm{O}_{5}(0,21 \%)$, kadar $\mathrm{K}_{2} \mathrm{O}(5,35 \%)$, kadar air (55\%), Kalsium (Ca) 4,2\%, serta unsur mineral mikro seperti Magnesium (0,5\%), Cu (20 ppm), Mn (684 ppm) dan Zn (144 ppm).

Penggunaan kompos jerami dengan dosis 2-6 ton/ha mampu menghasilkan sekitar 4-8 ton gabah/ha tanpa pemberian pupuk kalium, sedangkan bila disertai pemberian $50 \mathrm{~kg} \mathrm{KCl}$, aplikasi kompos jerami mampu menhasilkan padi hingga 9 ton/ha dan bila pemberian kompos jerami hasil tertinggi hanya sekitar 6 ton/ha 
walaupun sudah dipupuk dengan $150 \mathrm{~kg} \mathrm{KCl}$. Tampak jelas aplikasi kompos jerami mampu menurunkan penggunaan pupuk anorganik dengan signifikan. Diperkirakan aplikasi kompos jerami di negara tropis seperti Indonesia, akan mampu meningkatkan kandungan C-organik, ketersediaan hara, kesuburan tanah dan tanaman dengan signifikan.

Paparan di atas memperlihatkan bahwa pemberian kompos jerami antara lain berfungsi; (1) sebagai bahan atau agent pemulih kesuburan \& kualitas lahan sawah yang murah dan mudah diperoleh, (2) sebagai sumber hara lengkap (nutrisi) dengan komposisi yang optimal untuk mendukung pertumbuhan dan hasil tanaman padi, (4) sebagai pupuk organik untuk mengurangi penggunaan pupuk anorganik hingga $50 \%$ sedangkan untuk pupuk kalium dan silika (Si) dapat dikurangi hingga 100\%, (5) sebagai sumber energi dan nutrisi bagi organisme tanah menguntungkan, (6) memiliki efek residu untuk perbaikan kualitas lahan dan peningkatan produktivitas secara berkelanjutan.

\section{a. Tinjauan dari Aspek Teknis}

Kompos jerami padi memiliki potensi hara yang sangat tinggi yang dapat dimanfaatkan para petani Indonesia. Berikut ini hasil analisis kompos jerami padi dengan mikroba Trichoderma sp., Trenates sp., dan Aspergillus sp. yang dibuat dalam bak dengan waktu pengomposan 3 minggu: Rasio C/N (18,88), kadar C $(35,11 \%)$, kadar N $(1,86 \%)$, kadar $\mathrm{P}_{2} \mathrm{O}_{5}(0,21 \%)$, kadar $\mathrm{K}_{2} \mathrm{O} 5,35 \%$, kadar air (55\%), Kalsium (Ca) 4.2\%, serta unsur mikro Magnesium (Mg) 0.5\%, Cu 20 ppm, Mn 684 ppm dan Zn 144 ppm. Dari data di atas, setiap 1 ton kompos jerami padi memiliki kandungan hara dan kualitas produk akhir yang setara dengan $41,3 \mathrm{~kg}$ urea, $5,8 \mathrm{~kg} \mathrm{SP} 36$, dan $89,17 \mathrm{~kg} \mathrm{KCl}$ atau total 136,27 kg NPK (Setyorini, 2006).

Sementara itu beberapa faktor yang mempengaruhi penguraian jerami padi dalam pembuatan kompos adalah : a) Kandungan senyawa kimia jerami padi (kadar lignin 7-9\%, selulosa 33-35\%, hemiselulosa 26-28\%), semakin banyak bahan ini, semakin baik kulitas kompos jerami karena senyawa tersebut dapat dikomposkan oleh fungi menjadi sumber $\mathrm{C}$ dan $\mathrm{H}$ organik untuk tanaman. b) Ukuran jerami padi $(2-5 \mathrm{~cm})$, semakin halus bagian-bagian jerami padi yang digunakan maka proses penguraiannya akan berlangsung lebih cepat. Oleh karena itu, sebaiknya bahan-bahan yang akan digunakan untuk membuat kompos dipotong-potong terlebih dahulu. c) Kadar N bahan kompos (10\%), bahan asal yang kaya $\mathrm{N}$ akan cepat terurai karena jasad renik yang mengurai tersebut memerlukan $\mathrm{N}$ untuk pertumbuhannya. Oleh sebab itu pada pembuatan kompos perlu ditambah sedikit pupuk $\mathrm{N}$ buatan. d) $\mathrm{pH}$ tumpukan kompos ( $\mathrm{pH}$ 5-6), agar proses penguraian berlangsung cepat pH tumpukkan kompos tidak boleh terlalu rendah maka perlu diberi kapur ataupun abu dapur. e) Cukup mengandung air dan udara ( $\mathrm{O}_{2}$ ), kadar air optimal adalah sebesar 70-75\% apabila tumpukan kurang mengandung air, akan berjamur sehingga penguraiannya terhambat dan tidak sempurna. Sebaliknya bila terlalu banyak mngandung air, keadaanya menjadi anaerob yang akan merugikan mikroba perombak. f) Suhu Optimal bagi berlangsungnya proses perombakan adalah $30-45^{\circ} \mathrm{C}$. g) Porositas yaitu ruang antara partikel dalam tumpukan kompos. Porositas dihitung dengan mengukur volume rongga dibagi dengan volume total. Rongga-rongga ini akan diisi oleh air dan udara. Udara akan menyuplai oksigen untuk proses pengomposan. Apabila rongga dijenuhi oleh air, maka pasokan oksigen akan berkurang dan proses pengomposan juga akan terganggu. h) Kandungan Bahan Berbahaya, beberapa bahan organik mungkin mengandung bahan-bahan yang berbahaya bagi kehidupan mikroba. Logam-logam berat seperti Mg (pada kadar 1000 ppm), Cu (kadar $800 \mathrm{ppm}$ ), Zn (kadar 750 ppm), Nikel (kadar 950 ppm), Cr (kadar 450 ppm) adalah beberapa bahan yang termasuk kategori ini. Logam-logam berat akan mengalami imobilisasi selama proses pengomposan. j) Aerasi, pengomposan yang cepat dapat terjadi dalam kondisi yang cukup oksigen (aerob). Aerasi secara alami akan terjadi pada saat peningkatan suhu yang menyebabkan udara hangat keluar dan udara yang lebih dingin masuk ke dalam tumpukan kompos. Aerasi ditentukan oleh porositas dan kandungan air bahan (kelembaban). Apabila aerasi terhambat, maka akan terjadi proses anaerob yang akan menghasilkan bau yang tidak sedap. Aerasi dapat ditingkatkan dengan melakukan pembalikan atau mengalirkan udara di dalam tumpukan kompos.

Di dalam tumpukan bahan organik seperti pada pembuatan kompos selalu terjadi berbagai macam perubahan yang dilakukan oleh mikroba. Perubahan-perubahan itu antara lain: a). Penguraian bahan organik kompleks (selulosa, 
hemiselulosa, lignin) menjadi $\mathrm{CO}_{2}$ dan $\mathrm{H}_{2} \mathrm{O}$ atau $\mathrm{CH}_{4}$ dan $\mathrm{H}_{2}$ b). Penguraian protein menjadi amoniak, $\mathrm{CO}_{2}$ dan air, c). Pengikatan beberapa jenis unsur hara dalam tubuh jasad renik terutama $\mathrm{N}$ disamping $\mathrm{P}$ dan $\mathrm{K}$ yang akan terlepas kembali bila jasad itu mati, d). Pembebasan unsur hara dari senyawa organik menjadi senyawa anorganik yang tersedia bagi tanaman, e). Penguraian lemak dan lilin menjadi karbondioksida dan air. Akibat dari perubahan-perubahan tersebut diatas berat dan isi bahan-bahan itu sangat berkurang. Sebagian besar dari senyawa-senyawa karbon hilang ke udara (Perez dkk., 2002). Kadar senyawa $\mathrm{N}$ yang larut meningkat dan peningkatan ini akan tergantung pada perbandingan $\mathrm{C} / \mathrm{N}$ bahan asalnya. Dengan demikian nisbah $\mathrm{C} / \mathrm{N}$ semakin kecil dan akhirnya relatif konstan pada 15-22. Sejalan dengan perubahan-perubahan dan kehilangan karbon tersebut akan terjadi peningkatan kadar humus dalam bahan organik tersebut. Kualitas kompos jerami padi sangat tergantung kepada teknis pembuatan di lapangan. Untuk itu beberapa hal harus diperhatikan: a) Starter/ aktivator pengomposan yaitu mikroba yang digunakan harus berkualitas tinggi. Dalam hal ini starter inokulan yang ditambahkan yaitu $1 \mathrm{~kg}$ untuk $100 \mathrm{~kg}$ jerami padi akan mampu menghasilkan enzim lignoselulolitik dengan aktivitas yang tinggi, sehingga dapat mengkonversi substrat lignoselulosa jerami padi menjadi unsur hara seperti karbon (C) dan hidrogen $(\mathrm{H})$ yang penting untuk kesuburan tanah. b) Pembalikan kompos jerami padi dilakukan tiap minggu karena mikroorganisme pengurai jerami memerlukan aerasi atau udara selama proses fermentasi agar dapat bekerja secara optimal. c) Selain itu mikroba juga memerlukan kelembaban yang tinggi (RH sebesar 25-30\%) untuk mengomposkan jerami.

\section{b. Tinjauan dari Aspek Ekonomi}

Tinjauan analisis ekonomi dilakukan berdasarkan parameter total penerimaan, perhitungan laba rugi, nilai Return Cost Ratio, nilai Benefit Cost Ratio, dan Break Event Point. Berdasarkan analisis teknoekonomi selama produksi kompos dari jerami padi diketahui bahwa keuntungan atau laba (rugi) dapat diperoleh setelah penerimaan hasil penjualan produk dikurangi dengan harga pokok dan biaya produksi. Dimana untuk jumlah jerami padi sebanyak $860.000 \mathrm{~kg}$ akan dihasilkan pupuk kompos sebanyak 430.000 $\mathrm{kg}$ (430 ton/bulan) (Setyorini, 2006). Tabel 1 dan Tabel 2 menunjukkan jumlah penerimaan, biaya produksi, dan keuntungan yang diperoleh dari produksi kompos jerami.

Return Cost Ratio (R/C) adalah perbandingan antara penerimaan penjualan dengan biaya-biaya yang dikeluarkan selama proses produksi hingga menghasilkan produk. Usaha pembuatan pupuk kompos jerami akan menguntungkan apabila nila $\mathrm{R} / \mathrm{C}$ bernilai lebih dari 1 , sebagaimana perhitungan yang ditampilkan pada Tabel 3 . Berdasarkan data tersebut diketahui bahwa kegiatan pengolahan jerami padi sebagai kompos layak untuk direalisasikan dan cukup berprospek. Sebagai contoh nilai $\mathrm{R} / \mathrm{C}=1,2$ artinya bahwa setiap Rp 1.000,00 yang dikeluarkan akan menghasilkan tambahan penerimaan sebesar Rp 1.200,00.

Sementara itu Benefit Cost Ratio (B/C) adalah perbandingan antara tingkat keuntungan yang diperoleh dengan total biaya yang dikeluarkan.

Tabel 1. Perhitungan Total Penerimaan dari Produksi Kompos Jerami (Setyorini, 2006)

\begin{tabular}{cccccc}
\hline No & Jenis Kompos & Jumlah Produksi & Satuan & Harga Jual & Penerimaan \\
\hline 1. & Kompos curah & 430.000 & $\mathrm{~kg} / \mathrm{bulan}$ & 600 & 258.000 .000 \\
2. & Kompos Blok & 430.000 & $\mathrm{~kg} / \mathrm{bulan}$ & 600 & 258.000 .000 \\
3. & Kompos granula & 430.000 & $\mathrm{~kg} / \mathrm{bulan}$ & 1000 & 430.000 .000 \\
4. & Kompos bokhasi & 430.000 & $\mathrm{~kg} / \mathrm{bulan}$ & 2500 & 1.075 .000 .000 \\
\hline
\end{tabular}

Tabel 2. Perhitungan Laba/Rugi Perbulan Kompos Jerami (Setyorini, 2006)

\begin{tabular}{clccc}
\hline No. & Jenis Kompos & Penerimaan & Biaya Produksi & Keuntungan \\
\hline 1. & Kompos curah & 258.000 .000 & 215.000 .000 & 43.000 .000 \\
2. & Kompos Blok & 258.000 .000 & 215.000 .000 & 43.000 .000 \\
3. & Kompos granula & 430.000 .000 & 387.000 .000 & 43.000 .000 \\
4. & Kompos bokhasi & 1.075 .000 .000 & 1.032 .000 .000 & 43.000 .000 \\
\hline
\end{tabular}


Dalam analisis (B/C) ini akan diuji seberapa jauh nilai rupiah yang dipakai dalam kegiatan produksi kompos jerami dapat memberikan sejumlah nilai penerimaan sebagai manfaatnya Dengan kata lain analisis rasio penerimaan atas biaya produksi dapat digunakan untuk mengukur tingkat keuntungan relatif kegiatan produksi kompos jerami, artinya dari angka rasio penerimaan atas biaya tersebut dapat diketahui apakah produksi kompos jerami menguntungkan atau tidak. Usaha pengolahan jerami padi ini dikatakan layak dan memberikan manfaat jika nilai $\mathrm{B} / \mathrm{C}$ lebih besar dari 0. Dari Tabel 4 diketahui bahwa kegiatan pengolahan jerami padi menjadi kompos berdasarkan nilai rasio $\mathrm{B} / \mathrm{C}$ sangat layak untuk direalisasikan. Nilai $B / C=0,2$ artinya bahwa setiap Rp 1.000,00 yang dikeluarkan akan menghasilkan keuntungan sebesar Rp 200,00.

Sedangkan BEP (Break Event Poin) merupakan titik impas usaha. Dari nilai BEP ini dapat diketahui pada tingkat produksi dan harga berapa suatu usaha pengolahan jerami padi menjadi kompos tidak memberikan keuntungan dan tidak pula mengalami kerugian. Sebagaimana dapat dilihat pada Tabel 5, untuk pembuatan kompos curah usaha tidak mengalami kerugian atau memberikan keuntungan jika total produksi kompos curah sebanyak $358.333 \mathrm{~kg}$ atau harga pupuk kompos curah hanya Rp 500,00 per kg.

\section{Pemanfaatan Jerami Padi menjadi Silase}

\section{a. Tinjauan Aspek Teknis}

Silase adalah bahan yang dihasilkan dari fermentasi hijauan berkadar air tinggi (60-70\%) melalui proses yang disebut ensilase dalam tempat penyimpanan yang disebut silo. Ensilase merupakan proses penyimpanan hijauan yang bersifat anaerob dimana asam laktat diproduksi saat fermentasi yang menyebabkan $\mathrm{pH}$ turun hingga ke tingkat penurunan yang cukup bagi perkembangan mikroorganisme pemecah asam laktat dan asam amino membentuk asam butirat, amonia dan produk degradasi lain. Ensilase terjadi dalam 2 kondisi yaitu kondisi aerob

Tabel 3. Perhitungan R/C Produksi Kompos Jerami (Setyorini, 2006)

\begin{tabular}{clccc}
\hline No. & \multicolumn{1}{c}{ Jenis Kompos } & Penerimaan & Biaya Produksi & $\mathrm{R} / \mathrm{C}$ \\
\hline 1. & Kompos curah & 258.000 .000 & 215.000 .000 & 1,2 \\
2. & Kompos Blok & 258.000 .000 & 215.000 .000 & 1,2 \\
3. & Kompos granula & 430.000 .000 & 387.000 .000 & 1,1 \\
4. & Kompos bokhasi & 1.075 .000 .000 & 1.032 .000 .000 & 1,04 \\
\hline
\end{tabular}

Tabel 4. Perhitungan B/C Produksi Kompos Jerami Padi (Setyorini, 2006)

\begin{tabular}{clccc}
\hline No. & Jenis Kompos & Keuntungan & Total Biaya & $\mathrm{B} / \mathrm{C}$ \\
\hline 1. & Kompos curah & 43.000 .000 & 215.000 .000 & 0,2 \\
2. & Kompos Blok & 43.000 .000 & 215.000 .000 & 0,2 \\
3. & Kompos granula & 43.000 .000 & 387.000 .000 & 0,11 \\
4. & Kompos bokhasi & 43.000 .000 & 1.032 .000 .000 & 0,04 \\
\hline
\end{tabular}

Tabel 5. Perhitungan BEP Produksi Jerami Padi (Setyorini, 2006)

\begin{tabular}{lccccc}
\hline \multicolumn{1}{c}{ Jenis Kompos } & $\begin{array}{c}\text { Harga } \\
\text { Penjualan }\end{array}$ & $\begin{array}{c}\text { Total } \\
\text { Produksi }\end{array}$ & $\begin{array}{c}\text { Total Biaya } \\
(\times \text { sejuta })\end{array}$ & BEP Produksi & $\begin{array}{c}\text { BEP } \\
\text { Harga }\end{array}$ \\
\hline Kompos curah & 600 & 430.000 & 215 & 358.333 & 500 \\
Kompos Blok & 600 & 430.000 & 215 & 358.333 & 500 \\
Kompos granula & 1.000 & 430.000 & 387 & 387.000 & 900 \\
Kompos bokhasi & 2.500 & 430.000 & 1.032 & 412.800 & 2.400 \\
\hline
\end{tabular}


yang biasanya berjalan 4-6 jam dan kondisi anaerob setelah oksigen habis dipakai.

Karakteristik kualitas produk silase dari jerami padi adalah berbau asam, tidak berjamur, berwarna hijau kekuningan, memiliki $\mathrm{pH} 4,2$; kandungan asam laktat 1,5-2,5\%, kandungan asam butirat $0,1 \%$, kandungan asam asetat $0,5-0,8 \%$; dan kandungan $\mathrm{N}^{-\mathrm{NH}_{3}}$ 5-8\% (Yunilas, 2009). Silase memiliki beberapa kelebihan antara lain: ransum lebih awet, memiliki kandungan bakteri asam laktat yang berperan sebagai probiotik dan memiliki kandungan asam organik berperan sebagai growth promotor dan penghambat penyakit. Silase yang baik diperoleh dengan menekan berbagai aktivitas enzim yang berada dalam bahan baku yang tidak dikehendaki, namun dapat mendorong berkembangnya bakteri penghasil asam laktat.

Fermentasi jerami padi dengan starter mikroba Lactobacillus bulgaricus, Lactobacillus plantarum, dan Pledioccus pentosomonas akan meningkatkan kualitas nutrisi jerami padi. Hal ini ditunjukkan dengan peningkatan kadar protein kasar jerami padi dari 4,23\% menjadi $8,14 \%$ yang diikuti dengan penurunan kadar serat kasar. Fermentasi juga menurunkan kadar dinding sel jerami padi dari $73,41 \%$ menjadi $66,14 \%$. Hal tersebut menunjukkan bahwa telah terjadi pemecahan selulosa dinding sel jerami padi sehingga pakan akan lebih mudah dicerna oleh ternak.

Kualitas silase dicapai ketika asam laktat sebagai asam yang dominan diproduksi oleh mikroba dihasilkan secara cepat dengan konsentrasi yang tinggi. Semakin cepat fermentasi yang terjadi maka semakin banyak nutrisi yang dikandung silase dapat dipertahankan. Kualitas silase sangat dipengaruhi oleh 3 faktor yaitu a) karakteristik bahan (kandungan bahan kering, kapasitas buffer, struktur fisik dan varietas), b) tata laksana pembuatan silase (besar partikel, kecepatan pengisian ke silo, kepadatan pengepakan, dan penyegelan silo), c) keadaan iklim (suhu dan kelembaban). Pembuatan silase perlu ditambahkan bahan pengawet agar terbentuk suasana asam dengan derajat keasaman optimal. Bau asam dapat dijadikan sebagai indikator untuk melihat keberhasilan proses ensilase, sebab untuk keberhasilan proses ensilase harus dalam suasana asam dan secara anaerob. Tidak tumbuhnya jamur dalam proses pembuatan silase ini sangat penting untuk dipertahankan karena $\mathrm{pH}$ pertumbuhan optimum jamur adalah 4,0-6,5.
Upaya peningkatan kualitas gizi silase untuk pakan ternak juga dapat dilakukan dengan amoniasi. Amoniasi merupakan suatu cara pengolahan jerami padi secara kimiawi dengan menggunakan gas ammonia, $1 \mathrm{~kg}$ urea menghasilkan $0,57 \mathrm{~kg}$ gas ammonia. Tujuan amoniasi adalah untuk menguraikan ikatan serat yang sangat kuat pada dinding jerami tersebut agar selulosa dan hemiselulosa yang mempunyai nilai energi sangat tinggi bisa di cerna dan diserap oleh pencernaan ternak ruminansia. Kandungan urea pada proses amoniasi mempengaruhi tinggi rendahnya kandungan amoniak. Keuntungan dari proses amoniasi antara lain cara pengerjaannya tidak berbahaya, murah, menghilangkan kontaminasi mikroorganisme, meningkatkan protein kasar sampai dua kali lipat, meningkatkan jumlah konsumsi pakan karena jerami amoniasi lebih mudah dicerna. Ciri - ciri kualitas amoniasi yang baik yaitu berbau amonia menyengat, berwarna coklat tua, tekstur remah, $\mathrm{pH}$ basa dan tidak berjamur atau menggumpal, bersifat anaerob. Proses amoniasi ini dapat meningkatkan unsur-unsur kandungan nutrisi jerami padi yaitu dapat meningkatkan protein kasar dari $4 \%$ menjadi $7 \%$ serta dapat meningkatkan nilai kecernaan silase.

\section{b. Tinjauan Aspek Ekonomi}

Secara teknoekonomi, rincian biaya produksi silase melalui proses fermentasi jerami padi dapat dilihat pada Tabel 6 .

Tabel 6. Perhitungan Biaya Produksi Silase Jerami Padi

\begin{tabular}{clc}
\hline No & \multicolumn{1}{c}{ Keterangan } & $\begin{array}{c}\text { Harga/ ton } \\
\text { (Rp) }\end{array}$ \\
\hline 1 & Harga jerami padi & 100.000 \\
2 & Harga konsentrat & 600.000 \\
3 & Biaya pencacahan & 25.000 \\
4 & Biaya pencampuran & 25.000 \\
5 & Biaya pembungkusan & 25.000 \\
& Total biaya keseluruhan & 775.000 \\
\hline
\end{tabular}

Biaya produksi pembuatan silase jerami padi adalah sebesar Rp 775/kg atau Rp 775.000/ton. Dalam kondisi saat ini di pasaran silase jerami padi dijual dengan harga Rp 800.000/ton. Apabila dihitung nilai Benefit Cost Ratio dengan membagi harga jual silase jerami padi dengan 
biaya produksi yaitu 800.000/775.000 maka akan diperoleh nilai rasio 1,03. Berdasarkan hasil analisis kelayakan usaha tersebut dimana diperoleh nilai $\mathrm{B} / \mathrm{C}$ rasio sebesar 1,03 maka dapat diartikan bahwa setiap penambahan biaya sebesar Rp 1, akan memberikan penerimaan (nilai produksi) sebesar Rp 1,03. Karena nilai $\mathrm{B} / \mathrm{C}>1$ maka pembuatan silase jerami padi sangat layak untuk diusahakan.

Sementara itu untuk usaha peternakan yang berskala menengah ke atas atau lebih dari 20 ekor pemakaian silase jerami padi sebagai pakan ternak juga dapat memberikan efesiensi tenaga kerja. Pemeliharan ternak sapi dalam skala besar pada umumnya menggunakan tenaga kerja dalam jumlah yang banyak, sehingga dirasa kurang menghemat biaya, apabila dihitung upah yang digunakan untuk tenaga kerja lebih mahal dibandingkan dengan harga pakan yang diberikan. Upah tenaga kerja/orang adalah sebesar 500-700 ribu/bulan. Apabila pemeliharaan ternak sapi hanya mencapai 100 ekor dan perbandingan 10/1 maka peternak harus mengeluarkan biaya sebanyak $\mathrm{Rp}$ 6.000.000/bulan. Dalam pemeliharaan ternak sapi skala besar penggunaan pakan sebaiknya menggunakan pakan silase hasil fermentasi karena dengan pakan tersebut peternak tidak perlu lagi menyediakan lahan, menanam hijauan sebagai pakan ternak, tidak mengeluarkan biaya untuk membeli unit produksi pakan,dan menghemat biaya terutama tenaga kerja sebesar 50-70\%. Dengan pemberian pakan silase, peternak dapat menghemat biaya tenaga kerja sebesar Rp. 4.200.000./bulan atau sama dengan harga pakan sebesar 2,4 ton/bulan. Jumlah tersebut bisa dikonsumsi oleh sapi sebanyak 6 ekor/bulan dengan berat badan $200 \mathrm{~kg}$. Apabila kenaikan berat badannya perhari rata- rata 0,5 $\mathrm{kg}$, maka produksi daging per bulan minimal 90 kg x Rp 55.000 yaitu sebesar Rp 4.950.000.

\section{Pemanfaatan Jerami Padi menjadi Biogas}

Biogas adalah campuran gas yang dihasilkan oleh bakteri metanogenik yang terjadi pada material-material yang dapat terurai secara alami dalam kondisi anaerobik. Pada umumnya biogas dari jerami padi terdiri atas gas metana $\left(\mathrm{CH}_{4}\right) 50 \%-70 \%$, gas karbon dioksida $\left(\mathrm{CO}_{2}\right)$ $30 \%-40 \%$, hidrogen $\left(\mathrm{H}_{2}\right) 5 \%-10 \%$, dan gasgas lainnya dalam jumlah yang sedikit. Biogas memiliki berat $20 \%$ lebih ringan dibandingkan dengan udara bebas. Biogas memiliki suhu pembakaran antara $650^{\circ} \mathrm{C}-750^{\circ} \mathrm{C}$. Biogas tidak berbau dan tidak berwarna. Apabila dibakar, akan menghasilkan nyala api biru cerah seperti gas LPG. Nilai kalor gas metana adalah $20 \mathrm{MJ} /$ $\mathrm{m}^{3}$ dengan efisiensi pembakaran sebesar $60 \%$ pada kompor biogas konvensional (Khorshidi dan Arikan, 2008).

Gas metana hasil fermentasi jerami padi akan menyumbang nilai kalor yang dikandung biogas, besarnya antara $590-700$ kkal per kubik. Sumber utama nilai kalor biogas berasal dari gas metana ditambah sedikit dari $\mathrm{H}_{2}$ serta gas CO. Sedang karbon dioksida dan gas nitrogen tidak memiliki konstribusi dalam nilai kalor tersebut. Sementara dalam hal tingkat nilai kalor yang dimiliki, biogas memiliki keunggulan yang signifikan ketimbang sumber energi lainnya, seperti coalgas $\left(586 \mathrm{kkal} / \mathrm{m}^{3}\right)$ ataupun watergas (302 kkal/ $\left.\mathrm{m}^{3}\right)$. Nilai kalor biogas masih kalah dari gas alam $\left(967 \mathrm{kkal} / \mathrm{m}^{3}\right)$. Dalam setiap kubik biogas setara dengan $0.5 \mathrm{~kg}$ gas alam cair (liquid petroleum gases), 0,5 liter bensin dan 0,5 liter minyak diesel. Biogas pun dapat membangkitkan tenaga listrik sebesar 1,25-1,50 kilo watt hour $(\mathrm{kWh})$. Dari nilai kalor yang dikandung, biogas mampu dijadikan sumber energi dalam beberapa kegiatan sehari-hari. Mulai dari memasak, pengeringan, penerangan hingga pekerjaan yang membutuhkan pemanasan (pengelasan). Selain itu, biogas juga bisa dipakai sebagai bahan bakar untuk menggerakkan motor. Untuk keperluan ini, biogas sebelumnya harus dibersihkan dari kemungkinan adanya gas $\mathrm{H}_{2} \mathrm{~S}$ karena gas tersebut bisa menyebabkan korosi. Agar tak timbul gas yang berbau busuk, kita mesti melewatkan biogas pada ferri oksida. Nantinya ferri oksida inilah yang akan mengikat (gas) $\mathrm{H}_{2} \mathrm{~S}$. Bila biogas digunakan sebagai bahan bakar motor maka diperlukan sedikit modifikasi pada sistem karburator. Hasil kerja motor dengan bahan bakar biogas ini dapat dimanfaatkan untuk berbagai keperluan seperti pembangkit tenaga listrik, pompa air dan lainnya. Selain itu, biogas juga bisa dipadukan dengan sistem produksi lain.

\section{a. Tinjauan Aspek Teknis}

Secara umum energi biogas sangat potensial untuk dikembangkan. Beberapa alasannya adalah Pertama, produksi biogas dari jerami padi ditunjang oleh kondisi yang kondusif perkembangan pertanian di Indonesia. Kedua, regulasi di bidang energi seperti kenaikan 
tarif listrik, kenaikan harga LPG (Liquefied Petroleum Gas), premium, minyak tanah, minyak solar, minyak diesel dan minyak bakar telah mendorong pengembangan sumber energi alternatif yang murah, berkelanjutan dan ramah lingkungan. Ketiga, kenaikan harga dan kelangkaan pupuk anorganik di pasaran karena distribusi pemasaran yang kurang baik menyebabkan petani berpaling pada penggunaan pupuk organik.

Biogas sendiri mudah diterapkan di pedesaan dengan skala rumah tangga sebagai usaha multiguna. Pemanfaatan biogas di pedesaan adalah untuk bahan bakar kompor, penerangan, pemanas air dan penggunaan lainnya yang mendukung kegiatan industri kecil di pedesaan. Sedangkan lumpur keluaran dari digester dapat dimanfaatkan untuk pupuk atau dialirkan ke kolam ikan. Energi biogas dapat dimanfaatkan secara optimal dengan cara teringrasi dan penggunaan pada kegiatan-kegiatan yang produktif. Sehingga pemanfaatan energi biogas dapat memberikan dampak yang lebih luas dan dapat meningkatkan produktivitas, efisiensi serta nilai tambah pada produk. Dengan demikian, melalui kegiatan agribisnis ini diharapkan dapat menciptakan lapangan kerja dan menggairahkan perekonomian di pedesaan.

Selain potensi yang besar, pemanfaatan energi biogas dengan digester biogas memiliki banyak keuntungan, yaitu mengurangi efek gas rumah kaca, mengurangi bau yang tidak sedap, mencegah penyebaran penyakit, menghasilkan panas dan daya (mekanis/listrik) serta hasil samping berupa pupuk kompos. Pemanfaatan jerami padi dengan cara seperti ini secara ekonomi akan sangat kompetitif seiring naiknya harga bahan bakar minyak dan pupuk anorganik. Disamping itu, prinsip zero waste merupakan praktek pertanian yang ramah lingkungan dan berkelanjutan.

Produksi gas metana tergantung pada kondisi input (jerami padi), residence time, $\mathrm{pH}$, suhu dan toksisitas. Suhu digester berkisar 25$27^{\circ} \mathrm{C}$ menghasilkan biogas dengan kandungan gas metana $\left(\mathrm{CH}_{4}\right)$ sekitar $77 \%$. Berdasarkan perhitungan produksi biogas yaitu $6 \mathrm{~m}^{3} /$ hari, sedangkan hasil pengukuran tanpa beban menunjukkan laju aliran gas $1.5 \mathrm{~m}^{3} / \mathrm{jam}$ dengan tekanan $490 \mathrm{mmH}_{2} \mathrm{O}$ (lebih besar daripada perkiraan). Penggunaan lampu penerangan diperlukan biogas $0.23 \mathrm{~m}^{3} / \mathrm{jam}$ dengan tekanan $45 \mathrm{mmH}_{2} \mathrm{O}$ dan untuk kompor gas diperlukan biogas $0,30 \mathrm{~m}^{3} / \mathrm{jam}$ dengan tekanan $75 \mathrm{mmH}_{2} \mathrm{O}$.
Analisis dampak lingkungan dari limbah biogas yang keluar dari digester menunjukkan penurunan COD sebesar $90 \%$ dari kondisi bahan awal dan pebandingan BOD/COD sebesar 0.37 lebih kecil dari kondisi normal limbah cair BOD/COD yaitu sebesar 0,5. Sementara itu unsur utama $\mathrm{N}(1,82 \%), \mathrm{P}(0,73 \%)$ dan $\mathrm{K}$ $(0,41 \%)$ tidak menunjukkan perbedaan yang nyata dibandingkan pupuk kompos komersial (dengan kandungan $\mathrm{N}(1.45 \%), \mathrm{P}(1.10 \%)$ dan K $(1.10 \%)$. Berdasarkan hasil penelitian, hasil samping biogas berupa pupuk kompos mengandung lebih sedikit bakteri pathogen sehingga aman untuk pemupukan sayuran/buah, terutama untuk konsumsi segar.

Secara teknis penelitian pembuatan biogas dari jerami padi telah banyak dilakukan. Namun, permasalahan timbul karena jerami padi mengandung selulosa dan lignin yang sulit didegradasi sehingga menyebabkan permasalahan pada saluran pengeluaran. Untuk menanggulangi hal tersebut, perlakuan khusus terhadap jerami padi perlu dilakukan untuk mendegradasi lignin dengan cara biologi dan cara fisik. Jerami padi yang dipotong 5-8 $\mathrm{cm}$ kemudian dimasak dengan steam $220^{\circ} \mathrm{C}$ selama 5 menit akan meningkatkan yield gula dan hidrolisis enzimatis. Untuk meningkatkan produksi biogas dari jerami padi, kombinasi pretreatment dengan grinding, pemanasan dan treatment ammonia akan memperoleh yield yang tertinggi.

Pada proses fermentasi bahan, pada umumnya produksi biogas yang banyak dilakukan menggunakan sistem batch, dan memerlukan waktu yang panjang. Untuk mendapatkan produksi biogas yang lebih baik dan waktu tinggal (retention time) yang lebih cepat fermentasi bahan dilakukan dengan penggunaan kembali digestat dari proses fermentasi jerami sebagai starter pada proses fermentasi bahan berikutnya. Penggunaan kembali sebagian digestat ini diharapkan dapat mempercepat proses penguraian dan produksi biogas dari bahan jerami. Proses fermentasi berlangsung dari proses awal bahan baku input yang merupakan bahan organik (lignoselulosa) difermentasi oleh bakteri metanogenik secara anaerob sehingga menghasilkan biogas (gas metana) dan gas $\mathrm{CO}_{2}$. Dalam proses ini banyak faktor yang memfasilitasi dan menghambat proses fermentasi ini antara lain nilai $\mathrm{pH}$, suhu, laju pengumpanan, waktu retensi, toksisitas dan sludge. 


\section{- Nilai pH}

Produksi biogas secara optimum dapat dicapai bila $\mathrm{pH}$ dari campuran input di dalam digester berada pada kisaran 6 dan 7. Derajat keasaman $(\mathrm{pH})$ dalam digester juga merupakan fungsi waktu di dalam digester tersebut. Pada tahap awal proses fermentasi, asam organik dalam jumlah besar diproduksi oleh bakteri pembentuk asam, $\mathrm{pH}$ dalam digester dapat mencapai di bawah 5. Keadaan ini cenderung menghentikan proses fermentasi. Bakteribakteri metanogenik sangat peka terhadap $\mathrm{pH}$ dan tidak dapat bertahan hidup di bawah pH 6.6. Kemudian proses fermentasi berlangsung, konsentrasi $\mathrm{NH}_{4}$ bertambah sehingga dapat meningkatkan $\mathrm{pH}$ sehingga tercapai $\mathrm{pH}$ di atas 8. Ketika produksi metana dalam kondisi stabil, kisaran nilai $\mathrm{pH}$ adalah $7,2-8,2$.

\section{- Suhu}

Bakteri metanogen berada dalam keadaan tidak aktif pada kondisi suhu ekstrim tinggi maupun rendah, trend suhu menunjukkan bahwa produksi gas metana akan mulai terbentuk pada kisaran suhu $15-20^{\circ} \mathrm{C}$. Produksi gas metana terus meningkat pada suhu $25-30^{\circ} \mathrm{C}$ dan mencapai puncaknya pada suhu $35^{\circ} \mathrm{C}$. Hal tersebut juga menunjukkan bahwa suhu optimum pertumbuhan bakteri metanogenik dalam memproduksi gas metana adalah $35^{\circ} \mathrm{C}$. Selanjutnya peningkatan suhu hingga temperatur di atas $40^{\circ} \mathrm{C}$ justru mulai mengurangi produksi gas metana oleh bakteri metanogenik. Ketika suhu udara turun hingga mencapai $10^{\circ} \mathrm{C}$ maka produksi gas akan terhenti. Produksi gas sangat bagus yaitu pada kisaran mesofilik, antara suhu $25^{\circ} \mathrm{C}$ dan $30^{\circ} \mathrm{C}$. Penggunaan isolator yang memadai pada digester membantu produksi gas khususnya di daerah dingin.

\section{- Laju Pengumpanan}

Laju pengumpanan adalah jumlah bahan yang dimasukan ke dalam digester per unit kapasitas per hari. Pada umumnya laju pengumpanan yang digunakan adalah $6 \mathrm{~kg}$ jerami padi per $\mathrm{m}^{3}$ volume digester. Apabila terjadi pemasukan bahan yang berlebih, akan terjadi akumulasi asam dan produksi metana akan terganggu. Sebaliknya, bila pengumpanan kurang dari kapasitas digester, produksi juga menjadi rendah.

\section{- Waktu Tinggal di dalam Digester}

Waktu tinggal di dalam digester adalah ratarata periode waktu saat bahan baku masih berada dalam digester dan proses fermentasi dilakukan oleh bakteri metanogen. Dalam jaringan dari digester dengan jerami padi, waktu tinggal dihitung dengan pembagian volume total dari digester oleh volume input yang ditambahkan setiap hari. Waktu tinggal juga tergantung pada suhu. Di atas $35^{\circ} \mathrm{C}$ atau suhu lebih tinggi, waktu tinggal input semakin singkat.

\section{- Toksisitas}

Ion mineral, logam berat, dan detergen adalah beberapa material racun yang mempengaruhi pertumbuhan normal bakteri patogen di dalam digester. Ion mineral dalam jumlah kecil (sodium, potasium, kalsium, amonium, dan belerang) juga merangsang pertumbuhan bakteri. Namun, bila ion-ion ini dalam konsentrasi yang tinggi, maka akan berakibat meracuni. Sebagai contoh $\mathrm{NH}_{4}$ pada konsentrasi 50 hingga 200 $\mathrm{mg} / \mathrm{l}$, dapat merangsang pertumbuhan mikroba. Namun, bila konsentrasi di atas $1.500 \mathrm{mg} / \mathrm{L}$, akan mengakibatkan bakteri keracunan.

\section{- Sludge}

Sludge adalah limbah keluaran berupa lumpur dari lubang pengeluaran digester setelah mengalami proses fermentasi oleh bakteri metanogenik dalam keadaan anaerobik. Lumpur ini bebas patogen serta dapat dipergunakan untuk memperbaiki kesuburan tanah dan meningkatkan kesuburan tanaman (digunakan sebagai pupuk organik).

\section{b. Tinjauan Aspek Ekonomi}

Berdasarkan hasil analisis teknoekonomi yang dapat dilihat pada Tabel 7, pendapatan yang diperoleh dari instalasi biogas adalah sekitar Rp 600.000,00 per bulan bila dikonversikan dengan harga dan nilai kalori LPG (Liquefied Petroleum Gas). Asumsi ekonomi ini didasarkan pada data teknis bahwa $1 \mathrm{~m}^{3}$ biogas setara dengan $0,5 \mathrm{~kg}$ gas alam cair (liquid petroleum gases), sehingga apabila produksi biogas tiap bulan mencapai $180 \mathrm{~m}^{3}$, dengan laju produksi biogas per hari sebesar $6 \mathrm{~m}^{3}$ maka dapat disetarakan dengan produksi $90 \mathrm{~kg}$ elpiji. Jika 
Tabel 7. Parameter dan Hasil Analisis Kelayakan Ekonomi

\begin{tabular}{lc}
\hline Parameter & \\
\hline 1. Biaya investasi, Rp & 18.448 .000 \\
\hline Biaya operasional dan perawatan, Rp/tahun & 2.767 .200 \\
Pendapatan, Rp/tahun & 7.051 .800 \\
Keuntungan, Rp/tahun & 4.284 .600 \\
Umur ekonomi, tahun & 20 \\
Produksi gas, $\mathrm{m}^{3} / \mathrm{hari}$ & 6 \\
Produksi gas, $\mathrm{m}^{3} / \mathrm{tahun}$ & 2190 \\
Suku Bunga, $\% /$ tahun & 12 \\
\hline 2. Hasil Analisis Kelayakan Ekonomi & \\
\hline Net Present Worth $(\mathrm{NPW}), \mathrm{Rp}$ & 13.555 .578 \\
Net Present Cost (NPC), Rp & 39.117 .444 \\
Net Present Revenue (NPR), Rp & 52.673 .023 \\
B/C Ratio & 1.35 \\
Simple Payback, tahun & 4.3 \\
Internal Rate Return (IRR), \% & 23.70 \\
\hline
\end{tabular}

elpiji $12 \mathrm{~kg}$ harganya $\mathrm{Rp} 80.000,00$ maka dengan asumsi yang sama harga biogas sebesar $180 \mathrm{~m}^{3}$ dapat disetarakan menjadi Rp 600.000,00. Dengan menggunakan parameter dan analisis kelayakan ekonomi seperti pada Tabel 7 diperoleh B/C Rasio 1,35 yang berarti secara ekonomi investasi tersebut sangat layak dan berprospek untuk dikembangkan karena dapat memberikan keuntungan yang besar. Demikian pula dari hasil analisis simple payback diketahui bahwa modal investasi pembangunan konstruksi digester akan kembali pada tahun ke-4 (umur ekonomi digester adalah 20 tahun). Hasil pendapatan ini belum termasuk hasil samping berupa pupuk kompos.

\section{KESIMPULAN}

Fermentasi mikroba mampu mengolah limbah lignoselulosa dari jerami padi menjadi beberapa komoditas dengan nilai ekonomi yang cukup tinggi diantaranya menjadi kompos, biogas, dan silase.

Kompos jerami padi hasil fermentasi mikroba Trichoderma sp., Trametes sp., dan Aspergillus sp. memiliki kualitas sebagai berikut: Rasio C/N $(18,88)$, kadar C $(35,11 \%)$, kadar N $(1,86 \%)$, kadar $\mathrm{P}_{2} \mathrm{O}_{5}(0,21 \%)$, kadar $\mathrm{K}_{2} \mathrm{O}(5,35 \%)$, kadar air (55\%), Kalsium (Ca) 4,2\%, serta unsur mineral mikro seperti Magnesium (0.5\%), Cu (20 ppm), Mn (684 ppm) dan Zn (144 ppm). Sehingga setiap 1 ton kompos jerami padi memiliki kandungan hara setara dengan $41.3 \mathrm{~kg}$ urea, 5,8 kg SP36, dan
$89,17 \mathrm{~kg} \mathrm{KCl}$ atau total $136,27 \mathrm{~kg}$ NPK. Kualitas produk silase jerami padi hasil fermentasi Lactobacillus bulgaricus, Lactobacillus plantarum, dan Pledioccus pentosomonas adalah berbau asam, tidak berjamur, berwarna hijau kekuningan, memiliki $\mathrm{pH} 4,2$; kandungan asam laktat $1,5-2,5 \%$, kandungan asam butirat $0,1 \%$, kandungan asam asetat $0,5-0,8 \%$; dan kandungan $\mathrm{N}-\mathrm{NH}_{3} 5-8 \%$.

Biogas jerami padi hasil fermentasi bakteri metanogenik Methanobacterium dan Methanobacillus sangat berkualitas karena memiliki nilai kalor 590 - 700 kkal per kubik. Dalam setiap kubik biogas setara dengan 0,5 $\mathrm{kg}$ gas alam cair (liquid petroleum gases), 0,5 liter bensin dan 0,5 liter minyak diesel. Biogas jerami juga mampu membangkitkan tenaga listrik sebesar 1,25 - 1,50 kilowatt hour $(\mathrm{kWh})$. Biokonversi jerami padi menjadi biogas memiliki prospek ekonomi yang lebih baik untuk diaplikasikan dalam skala menengah maupun besar jika dibandingkan dengan biokonversi kompos dan silase.

\section{SARAN}

Perlu ada program sosialisasi dan penyuluhan kepada para petani tentang pemanfaatan jerami padi melalui fermentasi mikroba. Dengan adanya penyuluhan tersebut diharapkan akan meningkatkan kesadaran para petani terhadap nilai ekonomi yang tinggi dari jerami padi. Dengan 
memanfaatkan lignoselulosa jerami padi melalui teknologi fermentasi mikroba maka sebuah desa akan menjadi desa agroteknologi dan ramah lingkungan yang berswasembada pupuk kompos, mandiri energi melalui konversi biogas, serta berswasembada pakan ternak dengan produksi silase.

\section{DAFTAR PUSTAKA}

Ahamed, A.P., Vermette, 2008. Culture-based Strategies to Enhance Cellulase Enzyme Production from Trichoderma reesei RUT-C30 in Bioreactor Culture Conditions. Biochemical Engineering Journal 40, 399407.

Couto, S.R., Toca Hererra, J.L., 2007. Laccase production at reactor scale by filamentous fungi. Biotechnology Advances 25, 558-569.

Da Silva R., Lago E.S., Merheb, C.W., Machione, M.M., Park, Y.K., Gomes, E. 2005. Production of Xylanase and CMCase on Solid State Fermentation in Different Residues by Thermoascus auranticus Miehe. Brazilian Journal of Microbiology 36, 235 - 241.

Deublein, D. and Steinhauser, A., 2008. Biogas from Waste and Renewable Resource, WileyVCH Verlag GmbH \& Co. KGaA, Weinheim.

Dewi, 2002. Hidrolisis Limbah Hasil Pertanian Secara Enzimatik. Akta Agrosia 5 (2), 67 71.

Hartono, R. dan Kurniawan, T., 2009. Produksi Biogas dari Jerami Padi dengan Penambahan Kotoran Kerbau, Prosiding Seminar Nasional Teknik Kimia Indonesia- SNTKI 2009, Bandung, 19-20 Oktober 2009.

Howard, R.L., Abotsi, E., J. van Rensburg E.L., and Howard, S., 2003. Lignocellulose Biotechnology: Issue of Bioconversion and Enzyme Production. African J. of Biotech. Vol 2(12), 602-619.

Husen, E., Saraswati, R., Rachman A., 2007. Kompos, Manfaat dan Cara Membuatnya. Balai Penelitian Tanah, Bogor.

Jin, S., Chen, H., 2006. Superfine Grinding of Steam Exploded Rice Straw and Its Enzymatis Hydrolisis, Biochem Eng, J, 30, 225-230.

Khorshidi, N., Arikan, B., 2008. "Experimental Practice in order to Increasing Efficiency of Biogas Production by Treating Digestate of Sludge". Thesis. University College of Boras School of Engineering.

Mosier, N., Wayman C., Dale B., Elander, R., Lee Y.Y., Holtzapple M., Ladisch, M., 2005. Features of Promising Technologies for Pretreatment of Lignocellulose. Biores. Technol. 96, 673-686.
Murni, R., Suparjo, Akmal, dan Ginting B. L., 2008. Teknologi pemanfaatan Limbah untuk pakan. Laboratorium Makanan Ternak fakultas Peternakan Universitas, Jambi.

Perez, J., J.M. Dorado, T. Rubia, J. Martinez. 2002. Biodegradation and Biological treatments of Cellulose, Hemicellulose and Lignin: An Overview. Int. Microbiol. 5, 53-63.

Rachman, A., Dariah, A., dan Santoso, D., 2006. Pupuk hijau. hlm. 41-56. Dalam Pupuk Organik dan Pupuk Hayati. Balai Besar Penelitian dan Pengembangan Sumberdaya Lahan Pertanian, Bogor.

Saha, B.C., 2003. Hemicellulose Bioconversion. J. Ind. Microbiol. Biotechnol. 30: 279-291.

Saha, B.C., 2004. Lignocellulose Biodegradation and Application in Biotechnology. US Government Work. American Chemical Society. 2-14.

Setyorini, D., Saraswati R., dan Anwar E.K., 2006. Kompos. hlm.11- 40. Dalam Pupuk Organik dan Pupuk Hayati. Balai Besar Penelitian dan Pengembangan Sumberdaya Lahan Pertanian, Bogor.

Singhania, 2009. Cellulolytic Enzymes. Biotechnology for Agro-Industrial Residues Utilization. Chapter 20, 371-381.

Sukumaran, R.K., Singhania, R.R. and Pandey, A., 2005. Microbial Cellulases: Production, Applications and Challenges. J. of Scientific \& Industrial Res. Vol 64, 832-844.

Syamsu,. J.A., 2006. Kajian Penggunaan Starter Mikroba Dalam Fermentasi Jerami Padi Sebagai Sumber Pakan Pada Peternakan Rakyat di Sulawesi Tenggara. Dalam Seminar Nasional Bioteknologi. Puslit Bioteknologi LIPI: Bogor.

Taherzadeh, M. J. and Karimi, K., 2008. Pretreatment of Lignocellulosic Wastes to Improve Ethanol and Biogas: A Review, International Journal of Molecular Sci , 9, 1621-1651.

Taniguchi, M., Suzuki, H., Watanabe, D., Sakai, K., Hoshino, K., and Tanaka, T., 2005. Evaluation of Pretreatment with Pleurotus ostreatus for Enzymatic Hydrolysis of Rice Straw, Biosci, Bioeng, $J$, 100,637-43.

Yunilas, M.P., 2009. Bioteknologi Jerami Padi Melalui Fermentasi Sebagai Bahan Pakan Ternak Ruminansia. Karya Ilmiah. Departemen Peternakan. Fakultas Pertanian. Universitas Sumatera Utara. Medan. 